ROCZNIKI TEOLOGICZNE

Tom LXVI, zeszyt $10-2019$

DOI: http://dx.doi.org/10.18290/rt.2019.66.10-7

MARIA CHUCHRA

JULIA GORBANIUK

\title{
AKTYWNOŚĆ FIZYCZNA PIELĘGNIAREK. BADANIA PORÓWNAWCZE
}

\section{PHYSICAL ACTIVITY OF NURSES. COMPARATIVE STUDY}

\begin{abstract}
A b s t r a c t. Nurses are important promoters of health in society, so they must consciously take care of their health to serve as spokespersons for a healthy lifestyle and role models. Physical activity is one of the significant dimensions of health-related behaviors and a healthy lifestyle. The purpose of this article was to compare physical activity in the free time of nurses and women performing other professions.

The research included 100 nurses and 100 women doing other professions. The respondents were tested with the matched pair-selection method, taking into consideration two variables: a place of residence and age. The survey questionnaire that was used was prepared for the purpose of a smaller study. The research revealed that the main difference relates not to the forms of physical activity, but its frequency and this is usually related to the age of the participants. The most common forms of physical activity in both groups are walking and cycling. However, nurses practice them with much less frequency. The essential reason for this is because they have significantly less free time, both on working days and holidays. The main motive of physical activity for nurses is health (52\%) while in the control group - pleasure (35\%). Nurses also significantly more often perform prophylactic and are convinced about the necessity of leading a healthy lifestyle.
\end{abstract}

Key words: nurses; physical activity; lifestyle.

Dr hab. Maria Chuchra, prof. KUL - Katedra Zdrowia Publicznego, Instytut Nauk o Rodzinie i Pracy Socjalnej Katolickiego Uniwersytetu Lubelskiego Jana Pawła II, adres do korespondencji: Al. Racławickie 14, 20-950 Lublin; e-mail: mchuch@kul.pl

Dr hab. Julia Gorbaniuk, prof. KUL - Katedra Zdrowia Publicznego, Instytut Nauk o Rodzinie i Pracy Socjalnej Katolickiego Uniwersytetu Lubelskiego Jana Pawła II, adres do korespondencji: Al. Racławickie 14, 20-950 Lublin; e-mail: julia.gorbaniuk@kul.pl 


\section{WPROWADZENIE}

Liczne badania przeprowadzone w różnych państwach, często odmiennych kulturowo i odległych geograficznie, donoszą o niezadowalającym poziomie zachowań zdrowotnych pielęgniarek, przez co nie mogą one stanowić autorytetu dla pacjentów, których pielęgnują i edukują ${ }^{1}$. Wśród zachowań prozdrowotnych pielęgniarek niepokój budzi m.in. stosunkowo mała aktywność sportowa i rekreak cyjna w czasie wolnym od obowiązków rodzinnych i zawodowych. Donoszą o tym liczne badania, choć nie zawsze ich wyniki są porównywalne, co może wynikać ze stosowania różnych metod badawczych. W badaniach J. Bergier i współautorów stwierdzono wysoki poziom aktywności fizycznej wynikający z pracy zawodowej i obowiązków domowych. Natomiast największy udział w zajęciach rekreacyjnych i sportowych zadeklarowały panie z grupy najmłodszej i najstarszej $^{2}$. M. Zagroba wraz ze współpracownikami stwierdziła, że poziom aktywności fizycznej pielęgniarek był średni, a w większości przypadków odnotowywano brak systematyczności w zajęciach rekreacyjnych. Wraz z wiekiem malała liczba osób często uprawiających różnorodne ćwiczenia fizyczne, a wzrastała grupa przyznająca się do nieregularnego uprawiania ćwiczeń sportowo-rekreacyjnych ${ }^{3}$. Umiarkowaną aktywność fizyczną pielęgniarek wykazano w badaniach J. Książek i in., a preferowaną formą aktywności ruchowej przez $28 \%$ badanych był spacer ${ }^{4}$. Niewystarczającą aktywność fizyczną wśród pielęgniarek stwierdzono na Tajwanie. Badane pielęgniarki pozostawały bez ruchu przez ponad 8 godzin dziennie. Chociaż mają odpowiednią wiedzę zdrowotną, często nie stosują jej

${ }^{1}$ J.M. ZAPKA, S.C. Lemon, R.P. MAGNer, J. HALE, Lifestyle behaviours and weight among hospital-based nurses, „Journal of Nursing Management” 17(2009), nr 7, s. 853-860; B. JANKowsKa-Polańska, K. WiJAcka, K. Lomper, I. Uchmanowicz, Zachowania zdrowotne personelu pielęgniarskiego w profilaktyce nadciśnienia tętniczego, „Współczesne Pielęgniarstwo i Ochrona Zdrowia" 3(2014), nr 3 s. 67-70; L. Perry, X. Xu, R. Gallagher, R. Nicholls, D. Sibbritt, Сн. Duffield, Lifestyle Health Behaviors of Nurses and Midwives: The 'Fit for the Future' Study, „International Journal of Environmental Research and Public Health” 15(2018), nr 5, s. 945; doi:10.3390/ijerph15050945.

2 J. Bergier, B. Bergier, A. Soroka, Z. Kubińska, Aktywność fizyczna pielęgniarek z uwzględnieniem ich wieku, „Medycyna Ogólna” 16(2010), nr 4, s. 602.

${ }^{3}$ M. Zagroba, A. Kulikowska, M. Marcysiak, E. Wiśniewska, B. Ostrowska, G. SkotNiCKa-Klonowic, Aktywność fizyczna pielęgniarek, „Problemy Pielęgniarstwa” 18(2010), nr 3, s. 335.

${ }^{4}$ J. KsiążEK, P. JARZYNKOWSKi, R. PiOtrkowsKa, Wybrane elementy stylu życia pielęgniarek operacyjnych, „Medycyna Rodzinna” 2015, nr 3, s. 108. 
we własnym życiu. Prowadząc siedzący tryb życia, stają się grupą wysokiego ryzyka chorób cywilizacyjnych ${ }^{5}$.

Jak wykazują badania, pielęgniarki aktywnie ćwiczące, niepalące czy stosujące właściwą dietę, są bardziej skłonne do promowania takiego stylu życia niż te, które nie przestrzegają prozdrowotnych zaleceń ${ }^{6}$. Z kolei pacjenci są bardziej skłonni realizować zalecenia dotyczące prawidłowej diety czy ćwiczeń fizycznych oraz wykazują większe zaufanie wobec pielęgniarek, które mają prawidłową masę ciała ${ }^{7}$. Niektórzy podkreślają, że nawet młode osoby nie realizują w swoim życiu prozdrowotnych zasad, chociaż w trakcie kształcenia otrzymały większy zakres aktualnych informacji w tej dziedzinie niż ich starsze koleżanki ${ }^{8}$. Badania wykazują, że zalecenia promocji zdrowia wdrażane są raczej wybiórczo przez większość pielęgniarek i można tu raczej mówić o obecności poszczególnych elementów zachowań zdrowotnych, niż o realizacji prozdrowotnego stylu życia, który nawet w dużym uproszczeniu zakłada realizowanie jednocześnie kilku elementów ${ }^{9}$.

Ponieważ wyniki badań nadal często są sprzeczne, a świadomość skutków braku aktywności fizycznej wzrasta, istnieje potrzeba prowadzenia systematycznych badań w tym zakresie. Należy podkreślić, że pielęgniarki są ,strażnikami” zarówno zdrowia pacjenta, jak i zdrowia publicznego. Są ważnymi promotorami zdrowia społeczności, więc muszą bardziej świadomie dbać o własne zdrowie, aby służyć jako rzeczniczki promocji zdrowia i wzory do naśladowania ${ }^{10}$.

5 M-L. Lin, J-J. Huang, H-Y. Chuang, H-M. Tsai, H-H. Wang, Physical activities and influencing factors among public health nurses: a cross-sectional study, BMJ Open2018;8:e19959. doi:10.1136/bmjopen-2017-019959.

${ }^{6}$ K.L. Rush., C.C. KeE, M. Rice, Nurses as imperfect models of health promotion, „Western Journal of Nursing Research" 27(2005), nr 2, s. 166-183; J. RADSMA, J.L. BotToRfF, Counteracting ambivalence: nurses who smoke and their health promotion role with patients who smoke, „Research in Nursing \& Health” 32(2009), s. 443-452; A. RemigrońsKa, A. WŁoszczak-Szubzda, Zachowania zdrowotne pielegniarek czynnych zawodowo co najmniej jeden rok, „Aspekty Zdrowia i Choroby" 2016, nr 1, s. 41-53.

7 M. Hicks, L.L., Mcdermott, N. Rouhana, M. Schmidt, M.W. Seymour, T. Sullivan, Nurses' body size and public confidence in ability to provide health education, „Journal of Nursing Scholarship" 40(2008), nr 4, s. 349-354.

${ }^{8}$ K. JANKOWSKa-PolańsKa, K. WiJacka, I. Lomper, I. Uchmanowicz, Zachowania zdrowotne personelu pielęgniarskiego $w$ profilaktyce nadciśnienia tętniczego, „Współczesne Pielęgniarstwo i Ochrona Zdrowia" 3(2014), nr 3, s. 67-70; L. Perry L., X. Xu, R. Gallagher, R. Nicholls, D. Sibbritt D., Ch. Duffield, Lifestyle Health Behaviors of Nurses and Midwives: The 'Fit for the Future' Study, s. 945.

9 J. KSIĄ̇̇eK, P. JARZYNKOWSKI, R. PiotrkowsKa, Wybrane elementy stylu życia pielęgniarek operacyjnych, s.109.

10 M-L. Lin, J-J. Huang, H-Y. Chuang, H-M. Tsai, H-H. Wang, Physical activities. 
Celem niniejszego artykułu jest próba odpowiedzi na postawiony problem:

Czy aktywność fizyczna pielęgniarek i kobiet pracujących w innych zawodach różni się? Uszczegółowiając problem, można postawić następujące pytania badawcze:

Jakie formy aktywności ruchowej preferują pielęgniarki, a jakie kobiety $\mathrm{z}$ grupy kontrolnej?

Czy dysponują taką samą ilością czasu wolnego?

Czy różnią się w zakresie motywów warunkujących aktywność ruchową?

Czy istnieją różnice między oboma grupami dotyczące przeszkód utrudniających aktywność fizyczną?

\section{GRUPA BADANA I METODA}

W celu odpowiedzi na postawiony problem przebadano 100 pielęgniarek oraz 100 kobiet stanowiących grupę kontrolną, należących do różnych grup zawodowych. Kontrolowano zmienne demograficzne, dobierając osoby badane „metodą doboru parami” pod względem dwóch zmiennych: miejsca zamieszkania (wieś, miasto) oraz wieku respondentek. Grupa badawcza pielęgniarek była reprezentowana przez kobiety w wieku od 23 do 60 lat. Średnia wieku badanych kobiet wyniosła $\mathrm{M}=39,5$ roku. Były to kobiety, które w większości mieszkały w miastach $-60 \%$, zaś $40 \%$ kobiet pochodziło ze wsi. Grupa kontrolna kobiet pracujących w innych zawodach była analogiczna pod względem tych dwóch zmiennych.

Wykształcenie w obydwu grupach badanych było reprezentowane w ramach trzech kategorii: średnie zawodowe (28\% - pielęgniarki vs 34\% - grupa kontrola), wyższe zawodowe na poziomie licencjackim ( $34 \%$ - pielęgniarki vs $26 \%$ - grupa kontrola) oraz wykształcenie wyższe magisterskie (38\% - pielęgniarki vs $40 \%$ - grupa kontrola). Badane kobiety posiadały podobny stan cywilny; mężatki były reprezentowane przez 70\% pielęgniarek i 63\% kobiet z grupy kontrolnej, panny przez $17 \%$ pielęgniarek i $21 \%$ kobiet z grupy kontrolnej, natomiast kobiety rozwiedzione przez 6 pielęgniarek i 4 osoby z grupy kontrolnej. Pozostałe stany cywilne były bardzo podobnie reprezentowane przez kobiety zakwalifikowane do obydwu grup.

W badaniach posłużono się zbudowanym kwestionariuszem ankiety, służącym do badania Stylu życia mężczyzn i kobiet, składającym się z 79 pytań. W artykule wykorzystano wybrane pytania dotyczące aktywności fizycznej w różnych sferach życia. 


\section{WYNIKI}

W pierwszej kolejności badane osoby zapytano o rodzaj aktywności fizycznej, którą podejmują w czasie wolnym. Wśród zaproponowanych odpowiedzi respondentki mogły wskazać na aktualnie popularne formy aktywności fizycznej, takie jak: spacer, bieganie, jazda na rowerze, pływanie, aerobik, fitness, pilates itp., ćwiczenia na siłowni, gry zespołowe, turystyka, taniec, praca na działce, inne. Wyniki prezentuje wykres 1 .

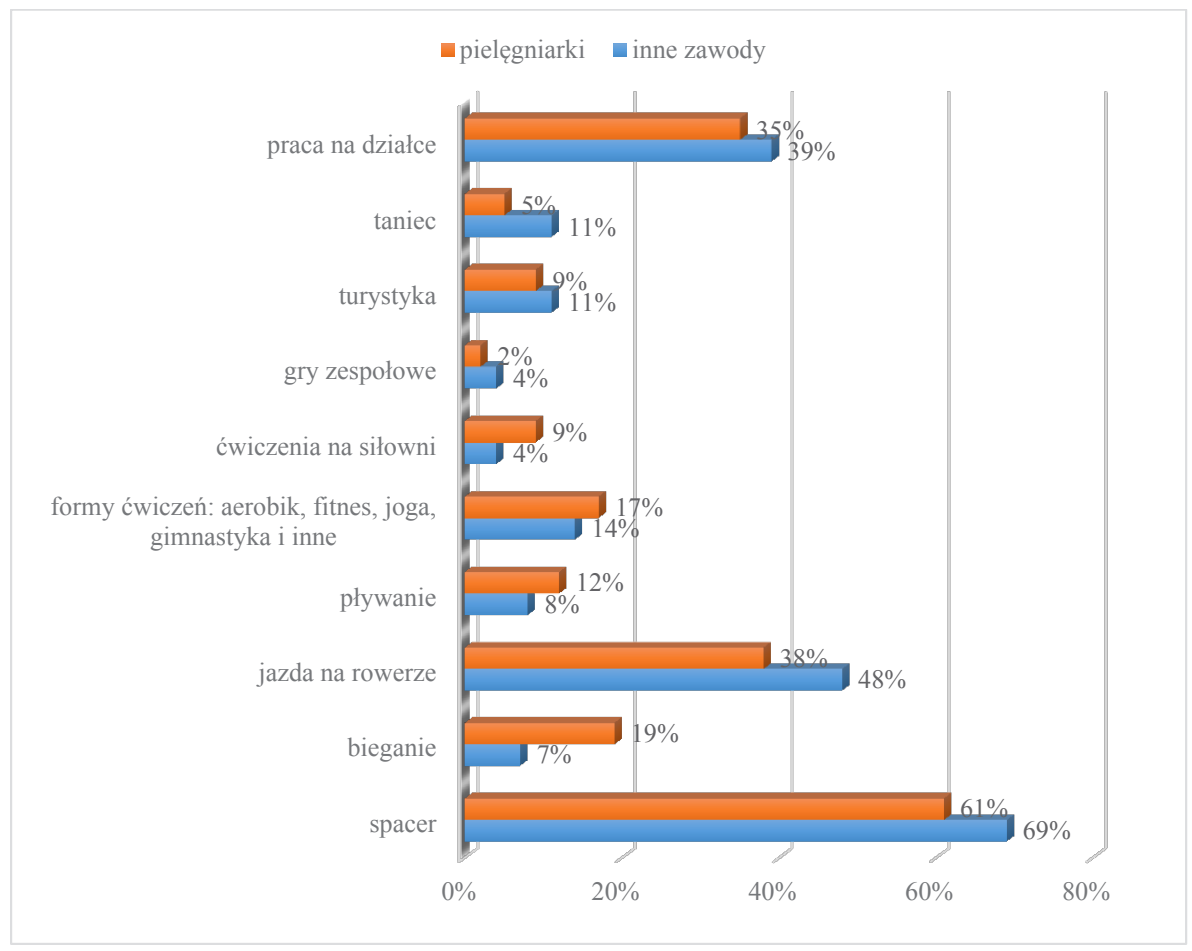

Wykres 1 . Formy aktywności fizycznej

$$
\left(\chi^{2}=5,663, d f=1, p=0,01\right)
$$

Analizując formy aktywności fizycznej podejmowane przez pielęgniarki i kobiety wykonywujące inne zawody, należy wskazać, że ogólnie wśród kobiet najbardziej popularne jest korzystanie ze spacerów, z tym że kobiety z grupy kontrolnej preferują tę aktywność częściej niż przedstawicielki służby zdrowia (pielęgniarki - 61\% vs inne zawody $-69 \%, p=0,01$ ). Kolejną formą aktywności fizycznej, do której skłaniają się respondentki, jest jazda na rowerze. Prawie połowa kobiet wskazuje, że preferuje jazdę rowerową na krótszych lub dłuższych 
dystansach. Sporo z nich zaznaczało też, że posiada rower stacjonarny. Zaobserwowana różnica między obydwiema grupami kobiet jest istotna statystycznie na poziomie $p=0,05$ i to na niekorzyść pielęgniarek. Z kolei pielęgniarki znacznie częściej deklarują bieganie jako sposób na podtrzymanie dobrej kondycji zdrowotnej (pielęgniarki - 19\% vs inne zawody - 7\%, $p=0,01$ ). Analizując osoby pod względem danych demograficznych, które zaznaczyły, że regularnie lub bardzo często biegają, stwierdzono, że są to przeważnie kobiety młode, do 30 roku życia $(p=0,05)$ oraz mieszkające w miastach $(p=0,01)$. Nie różniły się one zaś pod względem wykształcenia i stanu cywilnego. Bardzo popularną aktywnością fizyczną wśród ogółu kobiet jest praca na działce (pielęgniarki - 35\%, inne zawody - 39\%). Dotyczy to jednak przeważnie kobiet po 40 roku życia (65\%) oraz zamieszkujących na wsi (71\%). Z innych form aktywności fizycznych, częściej preferowanych przez pielęgniarki, należy wymienić ćwiczenia typu fitness (pielęgniarki - 17\% vs inne zawody - 14\%), pływanie (pielęgniarki $12 \%$ vs inne zawody $-8 \%$ ), ćwiczenia ogólnousprawniające (pielęgniarki - 9\% vs inne zawody $-4 \%$ ). Nie ujawniono natomiast różnic istotnych statystycznie dotyczących takich aktywności, jak turystyka oraz taniec. Znikoma zaś liczba badanych kobiet wskazała, że regularnie ćwiczy w ramach uprawiania sportów zespołowych typu piłka ręczna, nożna lub siatkówka (pielęgniarki - 2\% vs inne zawody -4\%). Badane również wskazywały na inne aktywności fizyczne, które uprawiają rekreacyjnie w zależności od sezonu (narciarstwo, łyżwy, rolki, nordic-walking, orbitrek).

W celu sprecyzowania, jak często respondentki korzystają z wybranych form aktywności fizycznej, zaproponowano im ustosunkowanie się do tych czynności na skali 5-stopniowej, gdzie wartość 1 oznacza sporadycznie, natomiast wartość 5 - regularnie. Wykres 2 prezentuje uzyskane wyniki.

Porównując obie grupy badanych kobiet, nie stwierdzono między nimi różnic pod względem częstotliwości uprawiania podanych form aktywności fizycznej. Generalnie największą grupę stanowią respondentki, które czynią to sporadycznie (ok. 45\% ogółu grupy). Z kolei około 30\% kobiet wskazało, że bardzo często podejmuje różne formy aktywności fizycznej. Regularnie ćwiczy ok. 16\% kobiet.

Według uzyskanych wyników badań należy stwierdzić, że wśród ogółu kobiet istnieje duża świadomość oraz potrzeba ruchu, gdyż tylko $13 \%$ pielęgniarek i 7\% kobiet wykonujących inne zawody deklarowało bardzo rzadkie lub sporadyczne korzystanie z jakichkolwiek form aktywności fizycznej w celu podtrzymania własnej sprawności i wydolności fizycznej, a wśród czynników najbardziej szkodzących zdrowiu respondentek najczęściej wymieniano niedostatek aktywności fizycznej. 


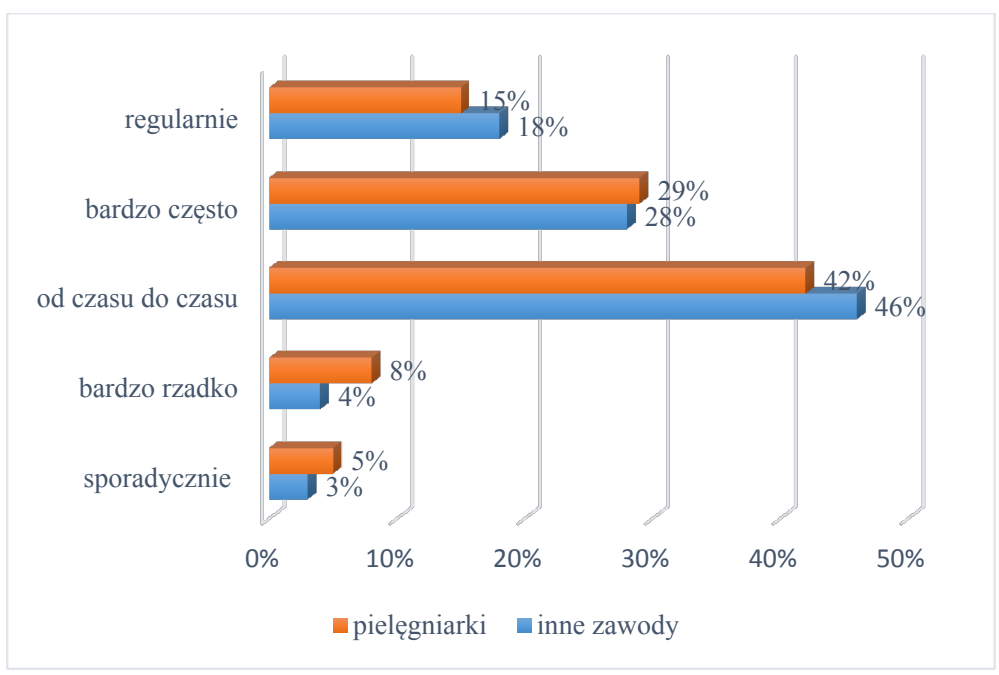

Wykres 2. Częstotliwość korzystania z wybranych form aktywności fizycznej

W kolejnym etapie badań starano się określić ilość czasu wolnego, którym dysponują obie grupy kobiet w ciągu dni roboczych i wolnych od pracy zawodowej. Uzyskane wyniki prezentują kolejno wykres 3 i wykres 4.

Otrzymane wyniki ukazują, że ponad 1/4 pielęgniarek (27\%) podaje, że w ciągu tygodnia roboczego wcale nie dysponuje wolnym czasem, natomiast wśród kobiet wykonywujących inne zawody tylko $7 \%$ jest podobnie obciążona obowiązkami. Stwierdzona różnica jest statystycznie istotna na poziomie $p=0,001$ (zob. wykres 3).

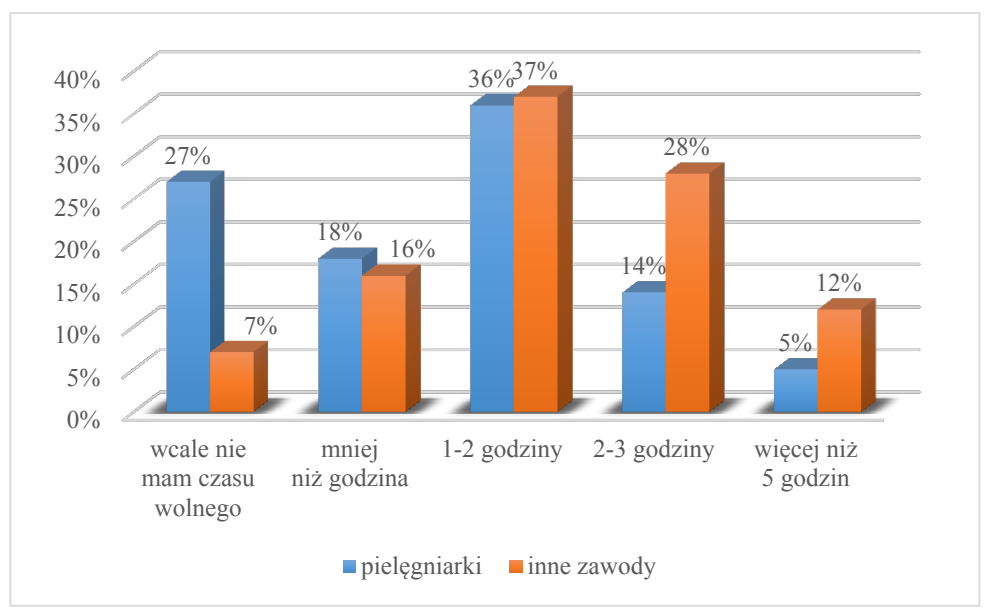

Wykres 3. Przeciętna ilość wolnego czasu w trakcie dni roboczych

$$
\left(\chi^{2}=19,445, d f=4, p=0,001\right)
$$


Kobiety wykonujące inne zawody stwierdzają, że są w stanie wygospodarować kilka godzin dziennie na własne potrzeby.

Analizując dane dotyczące wolnego czasu w dniach wolnych od pracy, należy wskazać, że zarówno pielęgniarki, jak i kobiety wykonywujące inne profesje, dążą do wygospodarowania czasu na odpoczynek, hobby czy regenerację po tygodniu pracy. Mimo to pielęgniarki również wypadają mniej korzystnie na tle grupy kobiet z grupy kontrolnej (pielęgniarki $-52 \%$ vs inne zawody $-74 \%, p=0,05$ ).

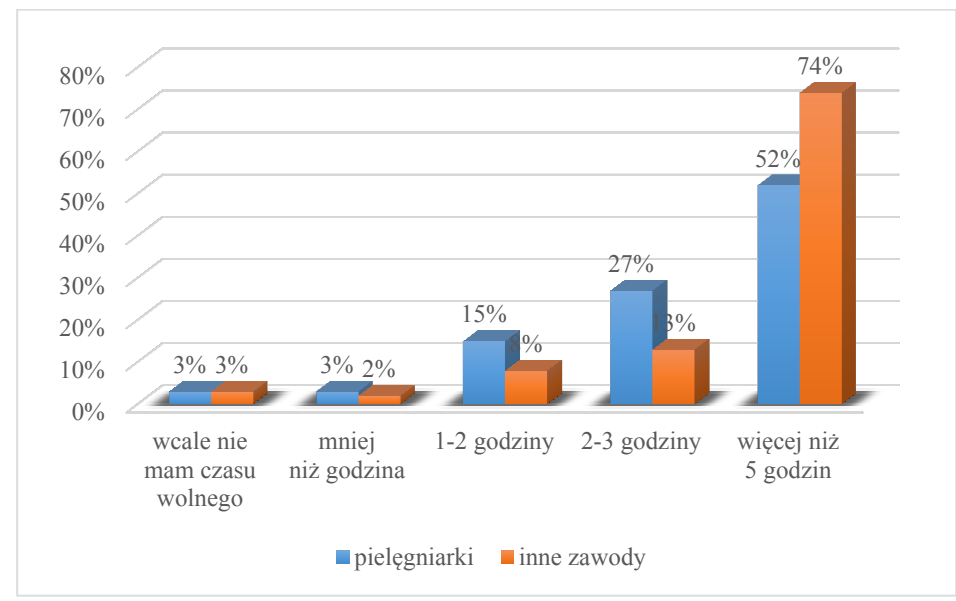

Wykres 4. Przeciętna ilość wolnego czasu w trakcie dni wolnych

$$
\left(\chi^{2}=11,072, d f=4, p=0,026\right)
$$

Respondentki zapytano także o ilość czasu przeznaczanego na aktywność fizyczną w ciągu dnia. Nie stwierdzono istotnych różnic między obydwiema grupami kobiet. Badane najczęściej poświęcają na tę czynność ok. pół godziny (ok. 60\%). Powyżej 1 godziny czasu regularnie na aktywność fizyczną poświęca $5 \%$ pielęgniarek oraz $8 \%$ kobiet wykonujących inne zawody.

Poświęcając czas wolny na aktywność fizyczną, kobiety kierują się różnymi motywami, które ukazuje tabela 1.

Otrzymane wyniki ujawniają, że najczęstszym powodem podejmowania aktywności fizycznej przez kobiety jest dbanie o własne zdrowie. Ten motyw jest szczególnie istotny dla pielęgniarek (pielęgniarki $-52 \%$ vs inne zawody $-33 \%, p=0,01$ ). Bezpośrednio ze zdrowiem łączy się motyw dotyczący poprawienia własnej kondycji zdrowotnej i dotyczy ponad 20\% badanych kobiet. Znacząca liczba kobiet (ok. 1/4 ogółu) wskazuje na przyjemność czerpaną z aktywności ruchowej. Stwierdzono również istotną różnicę między obydwiema grupami kobiet w aspekcie potrzeby ruchu. Kobiety wykonywujące inne zawody znacznie częściej wskazywały na nią jako na 
jeden z podstawowych motywów, natomiast pielęgniarki tylko w znikomym odsetku (pielęgniarki - $15 \%$ vs inne zawody $-33 \%, p=0,01$ ). Natomiast na motyw, jakim jest aktualna moda na zdrowy styl życia, wskazała marginalna część grupy badanej.

Tabela 1. Główne motywy podejmowania aktywności fizycznej

\begin{tabular}{|l|c|c|c|c|c|}
\hline \multicolumn{1}{|c|}{ Motywy } & Pielęgniarki & Inne zawody & $\chi \mathbf{2}$ & $\boldsymbol{d} \boldsymbol{f}$ & $\boldsymbol{p}$ \\
\hline zdrowie & $52 \%$ & $33 \%$ & $7,442 \mathrm{a}$ & 1 & 0,006 \\
\hline uroda & $11 \%$ & $12 \%$ & 0,049 & 1 & 0,824 \\
\hline poprawa kondycji fizycznej & $21 \%$ & $23 \%$ & $0,117 \mathrm{a}$ & 1 & 0,732 \\
\hline przyjemność & $25 \%$ & $35 \%$ & 2,391 & 1 & 0,122 \\
\hline kontakty towarzyskie & $2 \%$ & $4 \%$ & $0,688 \mathrm{a}$ & 1 & 0,407 \\
\hline potrzeba ruchu & $15 \%$ & $33 \%$ & $5,390 \mathrm{a}$ & 1 & 0,012 \\
\hline moda na zdrowy styl życia & $0 \%$ & $1 \%$ & 1,015 & 1 & 0,314 \\
\hline
\end{tabular}

W celu ustalenia barier zewnętrznych i wewnętrznych, które respondentki napotykają przy uczestniczeniu w aktywności fizycznej, podano do wyboru 5 propozycji, które w literaturze przedmiotu najczęściej występują. Są to: brak czasu wolnego ze względu na pracę zawodową i obowiązki rodzinne, brak łatwego dostępu do urządzeń sportowych/obiektów sportowo-rekreacyjnych, brak silnej woli, brak wiary w pozytywne skutki uprawiania aktywności fizycznej, brak środków finansowych oraz inne indywidualne przeszkody. Uzyskane wyniki badań prezentuje tabela 2.

Tabela 2. Bariery w podejmowaniu aktywności fizycznej

\begin{tabular}{|l|c|c|c|c|c|}
\hline \multicolumn{1}{|c|}{ Bariery } & Pielęgniarki & Inne zawody & $\chi \mathbf{2}$ & $\boldsymbol{d f}$ & $\boldsymbol{p}$ \\
\hline $\begin{array}{l}\text { brak wolnego czasu ze względu na } \\
\text { obowiązki }\end{array}$ & $68 \%$ & $63 \%$ & $0,556 \mathrm{a}$ & 1 & 0,456 \\
\hline brak dostępu do urządzeń /obiektów & $7 \%$ & $11 \%$ & $0,978 \mathrm{a}$ & 1 & 0,323 \\
\hline brak silnej woli & $33 \%$ & $36 \%$ & 0,200 & 1 & 0,655 \\
\hline $\begin{array}{l}\text { brak wiary w skuteczność aktywności } \\
\text { fizycznej }\end{array}$ & $4 \%$ & $5 \%$ & $0,116 \mathrm{a}$ & 1 & 0,733 \\
\hline brak środków finansowych & $0 \%$ & $1 \%$ & $1,026 \mathrm{a}$ & 1 & 0,311 \\
\hline indywidualne przeszkody & $35 \%$ & $37 \%$ & $0,081 \mathrm{a}$ & 1 & 0,776 \\
\hline
\end{tabular}

Porównanie obu grup badanych kobiet pod względem przeszkód jakie napotykają przy podejmowaniu aktywności fizycznej wskazuje na brak statystycznie 
istotnych różnic. Większość kobiet deklaruje brak wolnego czasu z powodu wykonywanych obowiązków zawodowych i rodzinnych (pielęgniarki - 68\% vs inne zawody - 63\%) oraz brak silnej woli niezbędnej do podejmowania regularnego wysiłku fizycznego (pielęgniarki - 33\% vs inne zawody - 36\%). Inne przeszkody, takie jak brak dostępu lub utrudniony dostęp do urządzeń i obiektów sportowo-rekreacyjnych czy brak środków finansowych na karnety lub zakup własnych urządzeń, w badanej grupie dotyczą nieznacznej liczby osób (3-11\%). Znacząca liczba respondentek, zarówno pielęgniarek, jak i kobiet wykonujących inne zawody, podawała szereg indywidualnych przeszkód, uniemożliwiających podjęcie celowej aktywności fizycznej.

Analizując ogólne przekonania dotyczące zachowań zdrowotnych badanych kobiet, należy podkreślić, że aktywność fizyczna znajduje się znacznie wyżej w rankingu niż pozostałe zachowania prozdrowotne, takie jak: zdrowe odżywianie się, regularne wykonywanie badań lekarskich i profilaktycznych, prowadzenie zdrowego stylu życia (tabela 3).

Tabela 3. Zachowania prozdrowotne

\begin{tabular}{|l|c|c|c|c|c|c|}
\hline \multirow{2}{*}{ Pytania } & \multicolumn{2}{|c|}{ Pielęgniarki } & \multicolumn{2}{c|}{ Inne zawody } & \multicolumn{2}{c|}{$\begin{array}{c}\text { Test U- } \\
\text { Mana Witneya }\end{array}$} \\
\cline { 2 - 7 } & $\boldsymbol{M}$ & $\boldsymbol{s} \boldsymbol{d}$ & $\boldsymbol{M}$ & $\boldsymbol{s} \boldsymbol{c}$ & $\boldsymbol{z}$ & $\boldsymbol{p}$ \\
\hline $\begin{array}{l}\text { regularnie korzystanie z form } \\
\text { aktywności fizycznej }\end{array}$ & 2,22 & 0,949 & 2,03 & 0,822 & $-0,247$ & 0,433 \\
\hline $\begin{array}{l}\text { przekonanie, że aktywność ruchowa } \\
\text { ma związek ze zdrowiem }\end{array}$ & 4,31 & 0,262 & 4,37 & 0,597 & 0,594 & 0,411 \\
\hline zdrowe odżywianie się & 3,11 & 0,952 & 2,96 & 0,942 & $-0,539$ & 0,880 \\
\hline $\begin{array}{l}\text { regularne wykonywanie } \\
\text { podstawowych badań lekarskich }\end{array}$ & 3,84 & 0,950 & 3,13 & 1,116 & $-1,097$ & 0,314 \\
\hline wykonywanie badań profilaktycznych & 3,91 & 0,922 & 3,05 & 1,165 & $-2,069$ & 0,045 \\
\hline prowadzenie zdrowego trybu życia & 3,42 & 0,917 & 2,63 & 0,913 & $-1,923$ & 0,044 \\
\hline
\end{tabular}

Odpowiedzi respondentek biorących udział w badaniu różniły się istotnie statystycznie pod względem wykonywania profilaktycznych badań lekarskich $(z=-2,069, p=0,05)$ oraz przekonania dotyczącego konieczności prowadzeniu zdrowego stylu życia $(z=-1,923, p=0,05)$ na korzyść pielęgniarek. Natomiast nie stwierdzono istotnych statystycznie różnic w zakresie przekonania o wartości aktywności fizycznej dla zdrowia, zdrowego odżywiania się czy faktycznego regularnego wykonywania badań podstawowych. Tego typu zachowania prozdrowotne są bardzo podobne w obydwu porównywanych grupach kobiet. 


\section{OMÓWIENIE WYNIKÓW}

Uzyskane wyniki ukazują, że najczęstszymi formami aktywności fizycznej w obu grupach kobiet są spacer, jazda na rowerze oraz praca na działce, przy czym dwie pierwsze formy są istotnie częściej preferowane w grupie kontrolnej niż wśród pielęgniarek. Spacery są popularne wśród 3/5 pielęgniarek (61\%) oraz zdecydowanej większości kobiet z grupy kontrolnej $(69 \%, p=0,01)$, zaś jazda na rowerze wśród niespełna $2 / 5$ pielęgniarek (38\%) i prawie połowy kobiet wykonujących inne zawody $(48 \%, p=0,05)$. Koresponduje to z wynikami raportu Kantar TNS i CEBOS, wg których Polacy najczęściej jeżdżą na rowerze ${ }^{11}$. Natomiast we wcześniejszych badaniach przeprowadzonych na grupie pielęgniarek przez J. Bergier i in. także spacery cieszyły się dużą popularnością (75\%), natomiast do jazdy na rowerze przyznało się aż 87,5\% badanych, a do biegania - 62,5\%, przy czym były to kobiety poniżej 40 roku życia ${ }^{12}$. Z kolei wśród pielęgniarek operacyjnych $28 \%$ preferowało spacery jako formę aktywności rekreacyjnej ${ }^{13}$. W niniejszych badaniach prawie 1/5 (19\%) pielęgniarek deklaruje, że biega, i w tym istotnie różni się od kobiet $\mathrm{z}$ grupy kontrolnej $(p=0,01)$. Są to zazwyczaj osoby młode (do 30 roku życia) i mieszkające w miastach. Tak więc można stwierdzić, że różnice dotyczą nie tyle form aktywności ruchowej, co jej częstości i jest to zazwyczaj związane z wiekiem badanych. Potwierdzają to także badania przeprowadzone wśród pielęgniarek we Francji. Wysoki poziom aktywności fizycznej dotyczył osób młodych, w wieku 21-30 lat ${ }^{14}$. Trzecia forma aktywności - praca na działce - nie wykazuje różnic istotnych statystycznie. Dotyczy ona jednak kobiet po 40 roku życia (65\%) i mieszkających na wsi (71\%).

Kolejne pytanie badawcze dotyczyło ilości czasu wolnego w dni robocze oraz w dni wolne od pracy. Otrzymane wyniki w obu sytuacjach są mniej korzystne w grupie pielęgniarek. Ponad 1/4 (27\%) pielęgniarek w dniach roboczych wcale nie dysponuje wolnym czasem, podczas gdy w grupie kontrolnej tylko 7\% kobiet jest podobnie obciążona obowiązkami ( $p=0,001)$. Porównywalny czas wolny $(1-2$ godziny) dotyczy tylko $2 / 5$ kobiet w obu grupach. Także w dni wolne od pracy pielęgniarki mają generalnie mniej czasu dla siebie. Zazwyczaj jest to mniej niż

11 Aktywność fizyczna Polaków 2017, https://sponsoringsport.pl/raport-aktywnosc-fizyczna-polakow-2017; Aktywność fizyczna Polaków, Warszawa: CBOS 2018, nr 125, s. 3.

12 J. Bergier, B. Bergier, A. Soroka, Z. KubińsKa, Aktywność fizyczna pielęgniarek z uwzględnieniem ich wieku, „Medycyna Ogólna” 16(2010), nr 4, s. 602.

13 J. KSIĄżEK, P. JARZYNKOWSKI, R. PIOTRKOWSKA, Wybrane elementy stylu życia pielęgniarek operacyjnych, s. 108.

14 A. Dubray, J. Bergier, I. GŁadysz, Role of physical activity in the lifestyle of French nurses, „Health Problems of Civilization” 2017, nr 4, s. 255. 
5 godzin. Natomiast więcej niż 5 godzin ma go 52\% pielęgniarek i 74\% kobiet wykonujących inne zawody, co także wskazuje na różnice istotne na niekorzyść tych pierwszych $(p=0,05)$. Brak czasu wolnego dla siebie jest częstym argumentem w wypowiedziach pielęgniarek także $w$ innych badaniach usprawiedliwiających ich niską aktywność fizyczną. W badaniach Bergier i in. zdecydowana większość badanych stwierdziła, że posiada zbyt małą ilość czasu wolnego. Wystarczająa cą ilość czasu wolnego posiadało najwięcej pielęgniarek z grupy najmłodszej, a najmniej $z$ grupy najstarszej ${ }^{15}$. W innych badaniach $32 \%$ pielęgniarek, które nie uprawiało żadnych ćwiczeń fizycznych, tłumaczyło ten fakt także brakiem wolnego czasu ${ }^{16}$. Jest to jeden z najczęściej powtarzających się powodów, podkreślanych zarówno przez pielęgniarki pracujące, jak i jeszcze uczące się ${ }^{17}$.

Porównując motywy podejmowania aktywności fizycznej, u pielęgniarek na pierwszym miejscu dostrzegamy „zdrowie” (52\%), na drugim „przyjemność” (25\%), zaś na trzecim „poprawę kondycji fizycznej” (21\%). Nieco inną hierarchię zauważamy w grupie kontrolnej. Pierwsze miejsce zajmuje „przyjemność” (35\%), na drugim usytuowały się „zdrowie” (33\%) oraz „potrzeba ruchu” (33\%), zaś na trzecim - „poprawa kondycji fizycznej” (23\%). Natomiast analizy statystyczne ujawniły dwie różnice istotne. Dla pielęgniarek istotnie częściej czynnikiem mobilizującym było zdrowie $(p=0,01)$, zaś dla osób spoza służby zdrowia potrzeba ruchu $(p=0,01)$. O tym, że zdrowie jest wartością szczególnie cenioną przez pielęgniarki, świadczą rezultaty różnych badań ${ }^{18}$. Wynika to zapewne stąd, że codziennie obserwują - niekiedy tragiczne - skutki jego braku. Zdrowie zazwyczaj sytuuje się wśród czołowych wartości także w innych grupach społecznych, co potwierdza także druga pozycja w badaniach Polaków w 2016 r., a pierwsza w 2018 r. przeprowadzonych przez CEBOS ${ }^{19}$.

Obie grupy nie różnią się natomiast pod względem przeszkód utrudniającym im podejmowanie aktywności ruchowej. W obu grupach na pierwszym miejscu

15 Aktywność fizyczna pielęgniarek z uwzględnieniem ich wieku, s. 602.

${ }^{16}$ M. Zagroba, A. Kulikowska, M. Marcysiak, E. Wiśniewska, B. Ostrowska, G. Skotnicka-Klonowic, Aktywność fizyczna pielęgniarek, „Problemy Pielęgniarstwa” 18(2010), nr 3, s. 335.

${ }^{17}$ Zob. H. Blake, N. Stanulewicz, F. Mcgill, Predictors of physical activity and barriers to exercise in nursing and medical students, „Journal of Advanced Nursing” 73(2017), nr 4, s. 917-929.

18 Zob. A. Deluga, B. Dobrowolska, B. Kosicka, A. Brzozowska, Wartościowanie zdrowia $w$ opinii pielegniarek $w$ odniesieniu do zmiennych społeczno-demograficznych, „Journal of Education, Health and Sport" 6(2016), nr 4, s. 167-180; A. Deluga, B. Dobrowolska, B. Kosicka, B. Ślusarska, M. JęDrych, A. Brzozowska, Znaczenie zdrowia w hierarchii wartości osobistych pielęgniarek, „Studia Medyczne” 34(2018), nr 1, s. 64-69; A. GórecZnA, W. GArCZYŃSKi, Motywy podejmowania aktywności fizycznej-przeglad literatury, „Health and Sport” 2017, nr 7, s. 322-337.

${ }^{19}$ Zdrowie i prozdrowotne zachowania Polaków, Warszawa: CBOS 2016, nr 138, s. 2; Aktywność fizyczna Polaków, Warszawa: CBOS 2018, nr 125, s. 6. 
wymieniono ,brak wolnego czasu ze względu na obowiązki” (pielęgniarki $68 \%$ vs inne zawody - 63\%), a następnie ,brak silnej woli” (33\% vs 36\%) oraz przeszkody indywidualne (35\% vs 37\%). Wśród nich najczęściej wymieniane to: pilniejsze sprawy do załatwienia, ograniczenia zdrowotne, zmęczenie z powodu obciążającej pracy zawodowej, bóle mięśni i stawów po dużym wysiłku. Z drugiej strony - jak wykazały badania - u pielęgniarek podejmujących co najmniej umiarkowaną aktywność fizyczną dolegliwości mięśniowo-szkieletowe występowały rzadziej. Prawdopodobnie rekreacyjna aktywność fizyczna o prozdrowotnych parametrach może stanowić skuteczną formę profilaktyki dolegliwości mięśniowo-szkieletowych, zwłaszcza u pielęgniarek ${ }^{20}$.

Dla pełności obrazu aktywność fizyczną porównano z innymi zachowaniami mającymi wpływ na zdrowie. W ich rankingu aktywność fizyczna usytuowała się znacznie wyżej (na pierwszym miejscu) niż takie zachowania zdrowotne, jak: prawidłowe nawyki żywieniowe, regularne wykonywanie badań lekarskich i profilaktycznych czy prowadzenie zdrowego stylu życia. Analizy porównawcze wykazały, że pielęgniarki istotnie częściej wykonują badania profilaktyczne $(z=-2,069, p=0,05)$ oraz są przekonane o konieczności prowadzenia zdrowego stylu życia $(z=-1,923, p=0,05)$. Taka postawa może wynikać z pracy w systemie służby zdrowia oraz większej świadomości pielęgniarek, że lepiej zapobiegać chorobom, niż je leczyć. Leczenie bowiem przewlekłych chorób cywilizacyjnych jest często bardzo uciążliwe i kosztowne. Pielęgniarki zdrowia publicznego są na pierwszej linii służby społeczeństwu. Jeśli nie zadbają o siebie, ich własne zdrowie ulegnie pogorszeniu i wpłynie to na jakość życia społeczeństwa ${ }^{21}$.

\section{BIBLIOGRAFIA}

Aktywność fizyczna Polaków, CBOS, Warszawa 2018, nr 125, s. 1-10.

Bergier J., Bergier B., Soroka A., Kubińska Z., Aktywność fizyczna pielęgniarek z uwzględnieniem ich wieku, „Medycyna Ogólna” 16(2010), nr 4, s. 595-605.

Blake H., Stanulewicz N., Mcgill F., Predictors of physical activity and barriers to exercise in nursing and medical students, ,Journal of Advanced Nursing” 73(2017), nr 4, s. 917-929.

Deluga A., Dobrowolska B., Kosicka B., Brzozowska A., Wartościowanie zdrowia w opinii pielęgniarek w odniesieniu do zmiennych społeczno-demograficznych, ,Journal of Education, Health and Sport" 6(2016), nr 4, s. 167-180.

20 W. Mynarski, M. Grabara, A. Nawrocka, M. NiestróJ-Jaworska, B. Wolkowyska, J. Cholewa, Rekreacyjna aktywność fizyczna i dolegliwości mięśniowo-szkieletowe pielęgniarek, „Medycyna Pracy” 65(2014), nr 2, s. 187.

${ }^{21}$ M-L. Lin, J-J. Huang, H-Y. Chuang, H-M. Tsai, H-H. Wang, Physical activities. 
Deluga A., Dobrowolska B., Kosicka B., Ślusarska B., Jędrych M., Brzozowska A., Znaczenie zdrowia w hierarchii wartości osobistych pielęgniarek, „Studia Medyczne” 34(2018), nr 1, s. 64-69.

Dubray A., Bergier J., GŁadysz I., Role of physical activity in the lifestyle of French nurses, „Health Problems of Civilization” 11(2017), nr 4, s. 253-260.

Góreczna A., GarczyŃski W., Motywy podejmowania aktywności fizycznej - przegląd literatury, „Heath and Sport” 2017, nr 7, s. 322-337.

Hicks M., Mcdermott L.L., Rouhana N., Schmidt M., Seymour M.W., Sullivan T., Nurses' body size and public confidence in ability to provide health education, „Journal of Nursing Scholarship" 40(2008), nr 4, s. 349-354.

Jankowska-Polańska B., WiJacka K., Lomper K., Uchmanowicz I., Zachowania zdrowotne personelu pielęgniarskiego w profilaktyce nadciśnienia tętniczego, „Współczesne Pielęgniarstwo i Ochrona Zdrowia" 3(2014), nr 3, s. 67-70.

Książek J., Jarzynkowski P., Piotrkowska R., Wybrane elementy stylu życia pielęgniarek operacyjnych, „Medycyna Rodzinna” 2015, nr 3, s. 103-109.

Lin M-L., Huang J-J., Chuang H-Y., Tsai H-M., Wang H-H., Physical act ivit ies and infl uencing factors among public health nurses: a cross-sectional study, BMJ Open2018;8:e019959, doi:10.1136/bmjopen-2017-019959.

Mynarski W., Grabara M., Nawrocka A., Niestrój-Jaworska M., Wolkowyska B., Cholewa J., Rekreacyjna aktywność fizyczna i dolegliwości mięśniowo-szkieletowe pielęgniarek, „Medycyna Pracy" 65(2014), nr 2, s. 181-188.

Perry L., Xu X., Gallagher R., Nicholls R., Sibbritt D., Duffield Ch., Lifest yle Heal th Behaviors of Nurses and Midwives: The 'Fit for the Future' Study, „Journal of Environmental Research and Public Health” 15(2018), nr 5, s. 945; doi:10.3390/ijerph15050945.

Radsma J., BottorfF J.L., 'Counteracting' ambivalence: nurses who smoke and their health promotion role with patients who smoke, ,Research in Nursing \& Health” 32(2009), s. 443-452.

Raport Aktywność fizyczna Polaków 2017, https://sponsoringsport.pl/raport-aktywnosc-fizyczna-polakow-2017.

RemigrońsKa A., WŁoszcZaK-SzubZda A., Zachowania zdrowotne pielęgniarek czynnych zawodowo co najmniej jeden rok, „Aspekty Zdrowia i Choroby” 2016, nr 1, s. 41-53.

Rush K.L., Kee C.C., Rice M., Nurses as imperfect models of health promotion, „Western Journal of Nursing Research" 27(2005), nr 2, s. 166-183.

Zagroba M., Kulikowska A., Marcysiak, M., Wiśniewska E., Ostrowska B., Skotnicka-Klonowic G., Aktywność fizyczna pielęgniarek, „Problemy Pielęgniarstwa” 18(2010), nr 3, s. 329-336.

Zapka J.M., Lemon S.C., Magner R.P., Hale J., Lifestyle behaviours and weight among hospital-based nurses, „Journal of Nursing Management” 17(2009), nr 7, s. 853-60.

Zdrowie i prozdrowotne zachowania Polaków, Warszawa: CBOS 2016, nr 138, s. 1-15.

\section{AKTYWNOŚĆ FIZYCZNA PIELĘGNIAREK. BADANIA PORÓWNAWCZE}

\section{Streszczenie}

Pielęgniarki są ważnymi promotorkami zdrowia społeczności, więc muszą bardziej świadomie dbać o własne zdrowie, aby służyć jako rzeczniczki promocji zdrowia i wzory do naśladowania. Aktywność fizyczna jest jednym z istotnych wymiarów prozdrowotnych zachowań i zdrowego stylu życia. Celem niniejszego artykułu było porównanie aktywności fizycznej w czasie wolnym od pracy pielęgniarek i kobiet wykonujących inne zawody. Przebadano 100 pielęgniarek i 100 osób 
z grupy kontrolnej. Kontrolowano zmienne demograficzne, dobierając osoby badane „metodą doboru parami” pod względem dwóch zmiennych - miejsca zamieszkania oraz wieku respondentek. W badaniach posłużono się zbudowanym dla niniejszych celów badawczych kwestionariuszem ankiety. Badania ujawniły, że różnice dotyczą nie tyle form aktywności ruchowej, co jej częstości i jest to zazwyczaj związane $\mathrm{z}$ wiekiem badanych. Najczęstszymi formami aktywności fizycznej w obu grupach są spacery i jazda na rowerze, ale pielęgniarki podejmują je znacznie rzadziej, gdyż mają istotniej mniej czasu wolnego, zarówno w dni robocze, jak i wolne od pracy. Głównym motywem aktywności fizycznej dla pielęgniarek jest zdrowie (52\%), zaś dla grupy kontrolnej przyjemność (35\%). Pielęgniarki także istotnie częściej wykonują badania profilaktyczne oraz są przekonane o konieczności prowadzeniu zdrowego stylu życia.

Słowa kluczowe: pielęgniarki; aktywność fizyczna; styl życia. 